\title{
ARTIFICIAL CRYSTALLIZATION OF VOLCANIC GLASS TO SODIUM AND POTASSIUM FORM OF CHABAZITE AT ROOM PRESSURE
}

\author{
Katsutoshi Tomita, Hiroyuki Yamashita and \\ NoBORU ŌBA \\ Institute of Earth Sciences, Facul'y of Science, Kagoshima University, \\ Kagoshima, Japan
}

\begin{abstract}
In this study we used volcanic glass from Kagoshima. In the system of glass $+\mathrm{NaOH}$, initial crystallization of the sodium form of chabazite occurs, followed by a gradual conversion to zeolite $\mathrm{X}$, and finally $\mathrm{Na}-\mathrm{P}$ zeolite begins to crystallize.

In the system of glass $+\mathrm{KOH}$, the potassium form of chabazite was formed after boiling for 14 hours.

High structure form of albite was formed from the codium form of chabazite upon heating at $530^{\circ} \mathrm{C}$ and the potassium form of chabazite was borken upon heating at $1000^{\circ} \mathrm{C}$.

There is replacement of the type $\mathrm{Ca} \leftrightarrow \mathrm{Na}_{2} \rightleftarrows \mathrm{K}_{2}$ in chabazite.
\end{abstract}

\section{INTRODUCTION}

Chabazite is typically found in crevices and amygdales in basalt and andesite, and related igneous rocks, where it occurs associated with stilbite, mesolite, mordenite, heulandite, apophyllite, etc. Chabazite also occurs in cavities and joints as a result of hydrothermal mineralization.

Many reports have been published concernig the hydrothermal synthesis of zeolites. The synthetic production of the potassium form of chabazite from a potassium aluminosilicate gel with appropriate composition which had been subjected to hydrothermal crystallization, was reproted by Barrer and Baynham (1956). Concerning synthesis of zeolite at room pressure only a few experiments have been reported (Sudo and Matsuoka, 1959).

Chabazite is one of the more common low-temperature zeolites. It can be regarded as a hydration product of volcanic glasses and lavas. This fact ied to a suggestion that the crystallization of chabazite may occur easily at low temperature and pressure among volcanic glass and various alkaline solutions.

This paper proposes to communicate that the chemical reactions easily occur at room pressure and temperature less than $100^{\circ} \mathrm{C}$ by digesting volcanic glass

(Manuscript received, April 16, 1969) 
with $\mathrm{NaOH}$ or $\mathrm{KOH}$ solution. Such observations have led to the industrial significance of sodium or potassium form of chabazite syntheses from naturally occuirrng materials, particularly volcanic glasses and pumice, in well defined experimental conditions.

\section{STARTING MATERIAL}

The original volcanic glass used for this study is found in widespread occurrence particularly in the southern part of Kyüshū, Japan. The mineral and chemical compositions, and the genesis of the volcanic glass which is socalled "Shirasu" were studied by Ōba, et al. (1967a, b). The chemical composition of the specimen collected from Gokoku-zinsha, Kagoshima city, Kagoshima prefecture is listed in Table 4 . The microscopic observation revealed that it consists of small amounts of feldspar, hypersthene, hornblende and quartz. After pulverzing to fine powder with an agate mortar, this specimen was used for experiments.

\section{EXPERIMENTAL}

One gram of powdered sample was boiled with $5 \%$ of $\mathrm{NaOH}$ or $\mathrm{KOH}$ solution. After boiling for a desired time, the sample was washed with distilled water by filtering until the filtrate showed no alkaline reaction. The washed sample was dried in air and investigated by $\mathrm{X}$-ray, differential thermal, infrared absorption and chemical analyses.

(A) Reaction between volcanic glass and $\mathrm{NaOH}$.

Observation was made on the reaction of one gram of powdered sample with $5 \% \mathrm{NaOH}$ solution in a glass jar upon heating it at about $100^{\circ} \mathrm{C}$ for various periods of time. During the first 6 hours none of zeolite phases were crystallized, but after boiling for 7 hours the initial crystallization of the sodium form of chabazite occured, followed by a gradual conversion to zeolite $\mathrm{X}$, and finally $\mathrm{Na}-\mathrm{P}$ zeolite of cubic form began to crystallize. Single phases of the sodium form of chabazite and zeolite $X$ could not be obtained. A single Na-P zeolite phase of cubic form was obtained when the run was carried for more than 20 hours. The Na-P zeolite phase of cubic form was stable and persisted up to 150 hours boiling. The $\mathrm{X}$-ray powder data of the specimens of zeolite $\mathrm{X}$ and $\mathrm{Na}-\mathrm{P}$ zeolite are listed in Table 1.

(B) Reaction between volcanic glass and $\mathrm{KOH}$.

One gram of powdered sample was boiled in $50 \mathrm{ml}$ of $5 \% \mathrm{KOH}$ solution for various periods of time. During the first 12 hours any zeolite phase could not be obtained, and the potassium form of chabazite was crystallized after boiling for more than 13 hours. A single phase of the potassium form of chabazite was obtained after boiling for more than 20 hours. At least the single phase 
Table 1. X-ray powder diffraction data for zeolite $\mathrm{X}$ and Na-P zeolite. $(\mathrm{CuKa})=1.5418 \AA$

\begin{tabular}{|c|c|c|c|c|c|}
\hline \multirow{2}{*}{ hkl } & \multicolumn{2}{|c|}{ zeolite $\mathrm{X}$} & \multirow{2}{*}{ hkl } & \multicolumn{2}{|c|}{ Na-P zeolite } \\
\hline & $\mathrm{d}(\dot{A})$ & I & & $\mathrm{d}(\dot{\mathrm{A}})$ & I \\
\hline 111 & 14.4 & 100 & 110 & 7.08 & 55 \\
\hline 220 & 8.76 & 65 & 200 & 5.01 & 31 \\
\hline 311 & 7.50 & 50 & 211 & 4.10 & 54 \\
\hline 222 & & & 310 & 3.16 & 100 \\
\hline 400 & & & 321 & 2.68 & 44 \\
\hline 331 & 5.72 & 65 & 400 & 2.51 & 8 \\
\hline 422 & & & 411,330 & 2.36 & 7 \\
\hline 333,511 & 4.85 & 35 & 422 & 2.05 & 3 \\
\hline 440 & 4.37 & 100 & 510,431 & 1.969 & 9 \\
\hline 620 & 3.90 & 65 & 440 & 1.774 & 4 \\
\hline 533 & 3.79 & 65 & 530,433 & 1.720 & 7 \\
\hline 622 & 3.75 & * & 600,422 & 1.669 & 6 \\
\hline 444 & 3.59 & * & 611,532 & 1.626 & 4 \\
\hline 551,711 & 3.50 & 50 & & & \\
\hline 642 & 3.34 & * & & & \\
\hline $\begin{array}{l}553,731 \\
800\end{array}$ & 3.25 & * & & & \\
\hline $\begin{array}{l}800 \\
644,820\end{array}$ & 3.02 & 50 & & & \\
\hline 660,822 & 2.93 & * & & & \\
\hline 555,751 & 2.85 & 35 & & & \\
\hline 840 & 2.79 & 50 & & & \\
\hline 911 & 2.73 & 35 & & & \\
\hline 664 & 2.65 & * & & & \\
\hline 931 & 2.62 & 35 & & & \\
\hline
\end{tabular}

* reflections overlapped by reflections of sodium form of chabazite or $\mathrm{Na}-\mathrm{P}$ zeolite.

persisted in boiling up to 200 hours.

\section{SYNTHESIZED SODIUM FORM OF CHABAZITE AND POTASSIUM FORM OF GHABAZITE}

$\mathrm{X}$-ray analysis

The sodium form of chabazite which was synthesized by 10 hours boiling was analysed. We could not obtain a single phase of sodium form of chabazite and in this sample a small amount of zeolite $\mathrm{X}$ was included. The X-ray powder data of the specimen are listed in Table 2 together with those of natural chabazite. Lattice dimensions were obtained from powder data: $a=13.56 \AA$, $c=15.27 \AA$, all being $\pm 0.02 \AA$. The unit cell dimensions of the zeolite were determined by the following method: Peaks were scanned at a rate of $1 / 4^{\circ} 2 \theta$ per minute on chart scale of $1 / 4^{\circ} 2 \theta$ per $\mathrm{cm}$. The silicon peak positions were 
Table 2. X-ray powder data of sodium form of chabazite and potassium form of chabazite. $(\mathrm{CuK} \alpha)=$ $1.5418 \mathrm{~A}$

\begin{tabular}{l|rr|rr|rr} 
& \multicolumn{2}{|c|}{1} & \multicolumn{2}{c|}{2} & \multicolumn{2}{c}{3} \\
\hline $\mathrm{hkl}$ & $\mathrm{d}(\AA)$ & $\mathrm{I}$ & $\mathrm{d}(\AA)$ & $\mathrm{I}$ & $\mathrm{d}(\AA)$ & $\mathrm{I}$ \\
\hline 101 & 9.5 & 70 & 9.50 & 71 & 9.35 & 45 \\
110 & 7.0 & 40 & 7.03 & 21 & 6.86 & 16 \\
012 & 6.4 & 10 & 6.46 & 7 & & \\
021 & 5.6 & 40 & 5.61 & 18 & 5.54 & 13 \\
003 & 5.0 & 40 & 5.09 & 25 & 5.04 & 14 \\
211 & 4.35 & 90 & 4.37 & 53 & 4.33 & 51 \\
122,300 & 3.90 & 20 & 3.91 & 35 & 3.87 & 29 \\
$*$ & 3.61 & 50 & 3.62 & 62 & 3.60 & 16 \\
220,104 & 3.47 & 20 & 3.48 & 18 & 3.44 & 11 \\
401 & 2.95 & 100 & 2.95 & 100 & 2.93 & 100 \\
410 & 2.62 & 20 & 2.62 & 9 & 2.61 & 18 \\
125,232 & 2.51 & 30 & 2.53 & 16 & 2.51 & 19 \\
333 & 2.10 & 20 & 2.10 & 12 & 2.09 & 10 \\
& 1.82 & 30 & 1.83 & 14 & 1.82 & 10 \\
& 1.74 & 20 & 1.71 & 9 & 1.73 & 10 \\
\hline
\end{tabular}

1. Chabazite from Herval, Santa Catherina, southeastern Brazil.

2. Sodium form of chabazite.

3. Potassium form of chabazite.

* Not indexed.

used as standards. The cell dimensions were calculated from the Qhkl values. Accuracy of $\pm 0.02 \AA$ was estimated for the unit cell measurement.

High structure form of albite was derived from the sodium form of chabazite upon heat treatment at $530^{\circ} \mathrm{C}$ for one hour. The X-ray powder data of the albite are listed in Table 3 .

The X-ray powder data of the potassium form of chabazite are given in Table 2 together with those of the sodium form of chabazite and natural chabazite. The X-ray powder data are similar to those of the sodium form of chabazite. The unit cell dimensions for the potassium form of chabazite are $a=$ $15.12 \AA, c=13.42 \AA$. The potassium form of chabazite collapsed on heat treatment at $1000^{\circ} \mathrm{C}$.

Differential thermal analysis

Differential thermal analysis curves were taken by an automatic thermal analyser at a heating rate of $10^{\circ} \mathrm{C}$ per minute for the sodium form of chabazite and the potassium form of chabazite. They are shown in Fig. 1 together with that of the original volcanic glass. The curve of the volcanic glass shows no 
Table 3. X-ray powder diffraction data for albite.

\begin{tabular}{|c|c|c|c|c|}
\hline \multirow{2}{*}{ hkl } & \multicolumn{2}{|c|}{ Natural Albite } & \multicolumn{2}{|c|}{ Synthesized Albite } \\
\hline & $\mathrm{d}(\AA)$ & $\mathrm{I}$ & $\mathrm{d}(\AA)$ & $\mathbf{I}$ \\
\hline $\begin{array}{l}020 \\
11 \overline{1} \\
1 \pi \\
20 \overline{1} \\
111\end{array}$ & $\begin{array}{l}6.37 \\
5.91 \\
5.61 \\
4.02 \\
3.85\end{array}$ & $\begin{array}{r}30 \\
4 \\
4 \\
34 \\
12\end{array}$ & 6.37 & 25 \\
\hline $\begin{array}{l}130 \\
130 \\
131 \\
112 \\
040\end{array}$ & $\begin{array}{l}3.79 \\
3.66 \\
3.51 \\
3.38\end{array}$ & $\begin{array}{l}43 \\
30 \\
12 \\
15\end{array}$ & $\begin{array}{l}3.76 \\
3.66 \\
3.48 \\
3.36 \\
3.20\end{array}$ & $\begin{array}{r}36 \\
32 \\
27 \\
65 \\
100\end{array}$ \\
\hline $\begin{array}{l}002 \\
220 \\
1 \overline{3} 1 \\
04 \overline{1} \\
02 \overline{2}\end{array}$ & $\begin{array}{l}3.19 \\
2.97 \\
2.93\end{array}$ & $\begin{array}{r}100 \\
20 \\
22\end{array}$ & $\begin{array}{l}3.18 \\
3.13 \\
3.02 \\
\\
2.93\end{array}$ & $\begin{array}{r}80 \\
25 \\
8 \\
48\end{array}$ \\
\hline $\begin{array}{l}222 \\
131 \\
1 \overline{3} \overline{2} \\
112\end{array}$ & $\begin{array}{l}2.87 \\
2.64 \\
2.56\end{array}$ & $\begin{array}{r}15 \\
9 \\
12\end{array}$ & $\begin{array}{l}2.84 \\
2.65 \\
2.52\end{array}$ & $\begin{array}{l}15 \\
17 \\
15\end{array}$ \\
\hline
\end{tabular}

Albite: From Amelia, Virginia, U.S.A.

reaction peaks. But the curves of both sodium and potassium forms of chabazite show only a broad endothermic peak between $100^{\circ} \mathrm{C}$ and $200^{\circ} \mathrm{C}$. The curve of the sodium form of chabazite shows an endothermic peak at about $150^{\circ} \mathrm{C}$ and the cruve of the potassium form of chabazite shows an endothermic peak at about $145^{\circ} \mathrm{C}$. The broad endothermic peak at about $150^{\circ} \mathrm{C}$ was identical to that of previous workers (Koizumi, 1953; Koizumi and Kiriyama, 1953).

Infrared absorption spectra

Infrared absorption spectra were obtained using a IR-6 type spectrophotometer with the Nujol past method. Fig. 2 shows spectra of the sodium form and potassium form of chabazite. Both spectra are quite similar and the bands of absorption around $3450 \mathrm{~cm}^{-1}$ are probably due to adsorbed water as indicated by comparison with montomorillonite data of Wolff (1965). The absorption bands at $3450 \mathrm{~cm}^{-1}$ in the water-stretching region are broad and spread twoard higher frequencies. This phenomenon has also been described in stilbite by Harada and Tomita (1967). It may be explained if a part of water in these zeolites is structurally bound. The absorption bands around $3600 \mathrm{~cm}^{-1}$ may be attributed to structurally bound water. A clear asymmetrical absorption at $1640 \mathrm{~cm}^{-1}$ due to adsorped water is visible. 

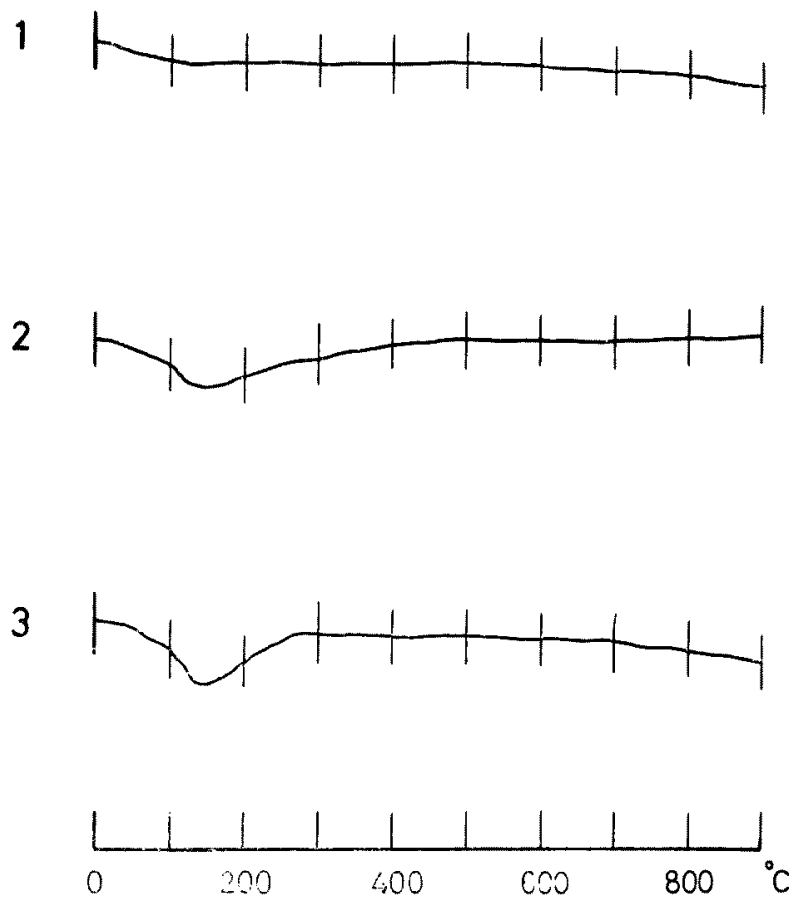

Fig. 1. Differential thermal analysis curves of volcanic glass (1), sodium form of chabazite (2) and potassium form of chabazite (3).

Chemical compositions

The specimens were analysed chemically. The results are listed in Table 4 together with that of the original volcanic glass. The sodium form of chabazite contains a remarkable amount of sodium. The potassium form of chabazite contains a remarkable amount of potassium. A hershelite variety from Sicily contains over 8 per cent of $\mathrm{Na}_{2} \mathrm{O}$ (Irrera, 1949), but such potassium form of chabazite has not previously been reported.

Amounts of Exchangeable Cations

Amounts of exchangeable cations of the sodium form and potassium form of chabazite were measured by the Schollenberger and Simon's method (Schollenberger and Simon, 1945). The Sodium form and potassium form of chabazite were pulverized in an agate mortar and $0.2 \mathrm{~g}$ of powdered sample was mixed with $2 g$ of quartz powder, and a complete mixture thus obtained was 


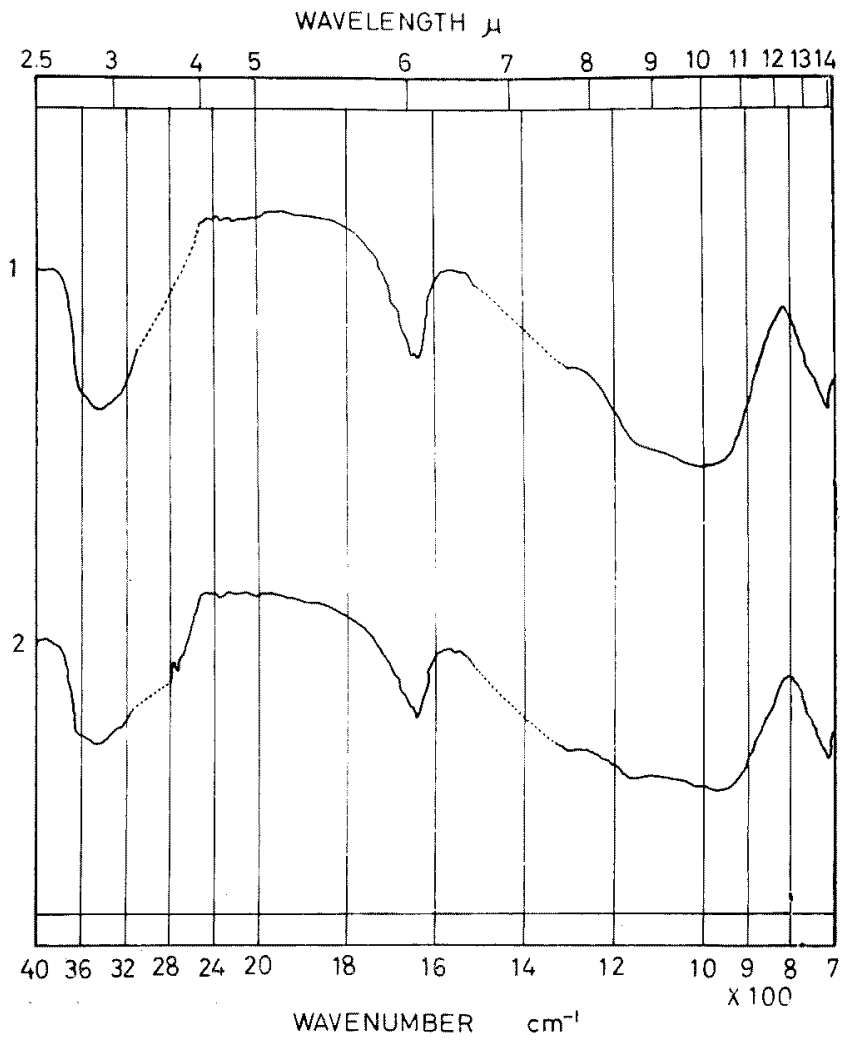

Fig. 2. Infrared absorption spectra of sodium form of chabazite (1) and potassium form of chabzite (2)

Note: Dotted line indicates the elimination of the peak due to Nujol.

packed into a glass tube, which is $12 \mathrm{~cm}$ in length and $1.3 \mathrm{~cm}$ in inner diameter with a stem of $4 \mathrm{~cm}$ length and $0.3 \mathrm{~cm}$ inner diameter. To prevent loss of the samples, absorbent cotton was placed at the bottom of the tube, Ammonium acetate solution $(\mathrm{pH}=7,1 \mathrm{~N}, 100 \mathrm{ml}$ ) was passed through the column for the duration between 7 and 10 hours. The amounts of exchangeable calcium and magnesium ions in the effluent were chemically determined and those of potassium and sodium ions were determined by flame photometer. The results are listed in Table 5 . The amount of exchangeable sodium ion in the sodium form of chabazite is larger than that of the potassium form of chabazite, whereas the potassium form of chabazite contains a remarkable 
Table 4. Chemical compositions of volcanic glass, sodium form of chabazite and potassium form of chabazite.

\begin{tabular}{|c|c|c|c|}
\hline No. & 1 & 2 & 3 \\
\hline $\mathrm{SiO}_{2}$ & $71.40 \%$ & $46.77 \%$ & $51.34 \%$ \\
\hline $\mathrm{TiO}_{2}$ & 0.25 & 0.24 & 0.46 \\
\hline $\mathrm{Al}_{2} \mathrm{O}_{3}$ & 13.65 & 17.80 & 19.14 \\
\hline $\mathrm{Fe}_{2} \mathrm{O}_{3}$ & 0.76 & 2.41 & 3.11 \\
\hline $\mathrm{FeO}$ & 1.55 & & \\
\hline $\mathrm{MnO}$ & 0.04 & 0.02 & - \\
\hline $\mathrm{MgO}$ & 0.48 & 0.93 & 0.75 \\
\hline $\mathrm{CaO}$ & 1.88 & 2.38 & 3.11 \\
\hline $\mathrm{Na}_{2} \mathrm{O}$ & 3.36 & 1.54 & 6.78 \\
\hline $\mathrm{K}_{2} \mathrm{O}$ & 2.70 & 11.70 & 1.94 \\
\hline $\mathrm{H}_{2} \mathrm{O}+$ & 3.40 & 7.82 & 6.62 \\
\hline $\mathrm{H}_{2} \mathrm{O}-$ & 0.62 & 7.66 & 6.20 \\
\hline $\mathrm{P}_{2} \mathrm{O}_{5}$ & 0.05 & 0.03 & 0.05 \\
\hline Total & $100.14 \%$ & $99.30 \% 6$ & $99.50 \%$ \\
\hline
\end{tabular}

1. Volcanic glass.

2. Potassium form of chabazite.

3. Sodium form of chabazite.

amount of exchangeable potassium ion as compared with that of the sodium form of chabazite.

\section{DISCUSSION}

The ideal composition of chabazite is $\mathrm{CaAl}_{2} \mathrm{Si}_{4} \mathrm{O}_{12} 6 \mathrm{H}_{2} \mathrm{O}$. Coombs et al. (1959) gave the composition as $\left(\mathrm{Ca}, \mathrm{Na}_{2}, \mathrm{~K}_{2}\right)_{5} \mathrm{Al}_{10} \mathrm{Si}_{26} \mathrm{O}_{72} .36 \mathrm{H}_{2} \mathrm{O}$ to $\left(\mathrm{Ca}, \mathrm{Na}_{2}, \mathrm{~K}_{2}\right.$ ) 6.75 $\mathrm{Al}_{13.5} \mathrm{Si}_{22.5} \mathrm{O}_{72} \cdot 36 \mathrm{H}_{2} \mathrm{O}$. Our experimental studies suggest that almost all $\mathrm{Ca}^{2+}, \mathrm{K}^{+}$and $\mathrm{Na}^{+}$in chabazite should be exchangeable, which is in contrast to the wairakite-analcime substitutions. Such replacement is possible from the stand point of the crystal structure of chabazite (Dent and Smith, 1958). This is common phenomenon in zeolites.

The potassium form and sodium form of chabazite were easily crystallized from volcanic glass at room pressure. This experiment suggests that NaOH and $\mathrm{KOH}$ seem to behave as catalyst in the course of crystallization of volcanic glass; probably it may take an important role to break the network linkage of $\mathrm{Si}(\mathrm{Al})$-oxygen in volcanic glass and facilitate the rearrangement of atoms toward new crystalline materials. This experiment is interesting from the industrial point of view. 
Table 5. Amounts of exchangeable cations of the sodium form of chabazite and the potassium form of chabazite. (me/ $100 \mathrm{~g}$ )

\begin{tabular}{cc|cc}
\hline sodium form of chabazite & $\begin{array}{l}\text { potassium } \\
\text { chabazite }\end{array}$ & form of \\
\hline $\mathrm{Na}^{+}$ & 200 & $\mathrm{Na}^{+}$ & 14 \\
$\mathrm{~K}^{+}$ & 3 & $\mathrm{~K}^{+}$ & 178 \\
$\mathrm{Mg}^{++}$ & 7.5 & $\mathrm{Mg}^{++}$ & 9.8 \\
$\mathrm{Ca}^{++}$ & 7.4 & $\mathrm{Ca}^{++}$ & 7.3 \\
\hline
\end{tabular}

\section{ACKNOWLEDGEMENTS}

The writers are indebted to Dr. M. Nakatani who provided convenience for the use of infrared spectrometer. The writers wish to thank all staffs of the Institute of Earth Sciences, Kagoshima University, for their valuable comments on this study. The present study has been supported by a Grant in Aid for Scientific Research from the Ministry of Education and a Grant from the Kagoshima Prefectural Scholarship Foundation.

\section{REFERNCES}

Barrer, R.M. and Baynham, J.W. (1956), The hydrothermal chemistry of the silicates. Part VII. Synthetic potassium aluminosilicates. Jour. Chem. Soc., 2882 2891 .

Coombs, D.S., Ellis, A.D., Fyfe, W.S. and Taylor, A.M. (1959), The zeolite facies, with comments on the interpretation of hydrothermal syntheses. Geochim. et Cosmochim. Acta, 17, 53 107.

Dent, L.S. and Smith, J.V. (1958), Crystal structure of chabazite, a molecular sieve. Nature, 181, $1794 \sim 1796$.

Harada, K. and Tomita, K. (1967), A sodian stilbite from Onigajō, Mié Prefecture, Japan, with some experimental studies concerning the conversion of stilbite to wairakite at low water vapor pressures. Amer. Miner., 52, $1438 \sim 1450$.

Irrera, G. (1949), In Rock-Forming Minerals, vol. 4, p. 403. Ed. by Deer, W. A., Howie, R.A. and Zussaman, J.

Koizumi, M. (1953), The differential thermal analysis curves and the dehydration curves of zeolites. Miner. Jour., 1, $36 \sim 47$.

- and Kiriyama, R. (1953), Structural changes of zeolites due to their thermal dehydrations. (Studies on water in minerals, Part 3). Sci. Rep. Osaka Univ., $67 \sim 85$.

Ōba, N., Tsuyuki, T. and Ebihara, H. (1967a), Mineral and chemical compositions, and genesis of the Shirasu (I). Jour. Japan. Assoc. Min. Pet. Econ. Geol., 58, 81 97 (in Japanese).

tions, and genesis of the Shirasu (II). Jour. Japan. Assoc. 
Pet. Econ. Geol., 58, $152 \sim 160$ (in Japanese).

Schollenberger, C.J. and Simon, R.N. (1945), Determination of exchange capacity and exchangeable bases in soil-ammonium acetate method. Soil Sci., 59, $13 \sim 24$.

Sudo, T. and Matsuoka, M. (1959), Artificial crystallization of volcanic glass to sodalite and a zeolite structure. Geochim, et Cosmochim. Acta, $17,1 \sim 5$.

Wolff, R.G. (1965), Infrafed absorption patterns (OH region) of several clay minerals. Amer. Miner., 50, $240 \sim 244$.

\section{常圧下での火山ガラスからのナトリウム質リヨウ沸石 \\ とカリウム質リョウ沸石人工結晶化}

富田克利・山下広幸・大庭开

摘要

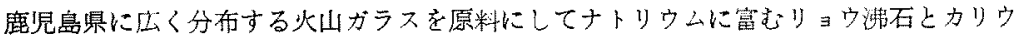

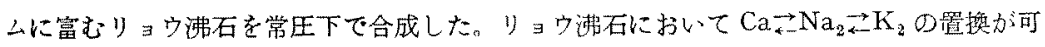
能であることがわかった。ナトリウムに富むりョウ沸石を $530^{\circ} \mathrm{C} て ゙ 1$ 時間加熱すること によって曹長石が生成した。 